\title{
Generation of 1,2-oxathiolium ions from (arysulfonyl)- and (arylsulfinyl)allenes in Brønsted acids. NMR and DFT study of these cations and their reactions
}

\author{
Stanislav V. Lozovskiy ${ }^{1}$, Alexander Yu. Ivanov ${ }^{2}$, Olesya V. Khoroshilova ${ }^{1}$ \\ and Aleksander V. Vasilyev ${ }^{*} 1,3, \S$
}

\section{Full Research Paper}

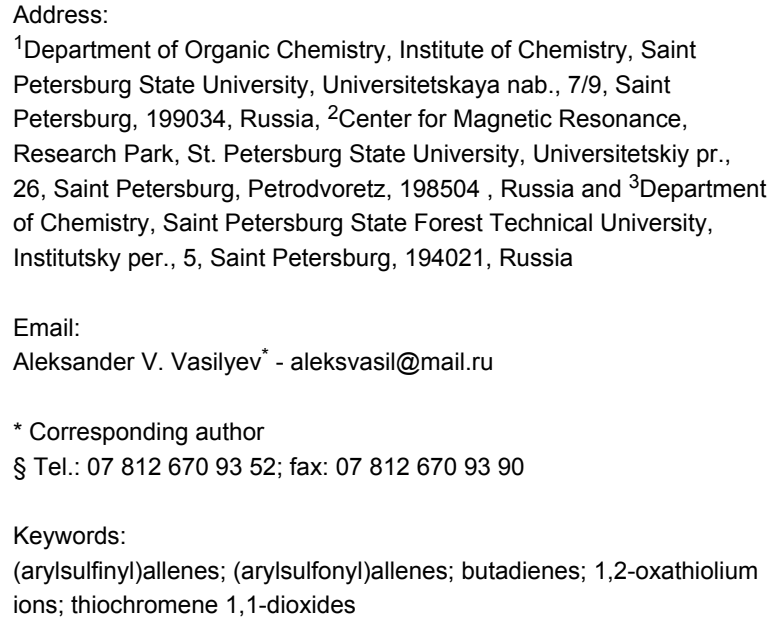

\author{
Beilstein J. Org. Chem. 2018, 14, 2897-2906. \\ doi:10.3762/bjoc. 14.268
}

Received: 08 August 2018 Accepted: 07 November 2018

Published: 22 November 2018

Associate Editor: T. P. Yoon

(c) 2018 Lozovskiy et al.; licensee Beilstein-Institut. License and terms: see end of document.

\begin{abstract}
In strong Brønsted acids $\left(\mathrm{CF}_{3} \mathrm{SO}_{3} \mathrm{H}, \mathrm{FSO}_{3} \mathrm{H}, \mathrm{D}_{2} \mathrm{SO}_{4}\right)$, (arysulfonyl)allenes $\left(\mathrm{ArSO}_{2}-\mathrm{CR}^{1}=\mathrm{C}=\mathrm{CR}^{2} \mathrm{R}^{3}\right)$ and (arylsulfinyl)allenes (ArSO-CR ${ }^{1}=\mathrm{C}=\mathrm{CR}^{2} \mathrm{R}^{3}$ ) undergo cyclization into the corresponding stable 1,2-oxathiolium ions, which were studied by means of NMR and DFT calculations. Quenching of solutions of these cations with low nucleophilic media, aqueous $\mathrm{HCl}$, leads to their deprotonation with a stereoselective formation of (arysulfonyl)butadienes (for instance, $\mathrm{ArSO}_{2}-\mathrm{CR}^{1}=\mathrm{C}-\mathrm{C}(\mathrm{Me})=\mathrm{CH}_{2}$, for $\mathrm{R}^{2}=\mathrm{R}^{3}=\mathrm{Me}$, yields of 87-98\%). Reactions of (arysulfonyl)allenes in the system TfOH (0.1 equiv)-HFIP (hexafluoropropan-2-ol) followed by hydrolysis give rise to allyl alcohols $\left(\mathrm{ArSO}_{2}-\mathrm{CR}^{1}=\mathrm{CH}-\mathrm{C}(\mathrm{OH}) \mathrm{R}^{2} \mathrm{R}^{3}\right.$, yields of $\left.78-99 \%\right)$. Reflux of solutions of (arysulfonyl)allenes in the presence of TfOH (1 equiv) in 1,2-dichlorobenzene leads to the cyclization into thiochromene 1,1-dioxides in high yields. Under the action of $\mathrm{TfOH}$ or $\mathrm{AlX}_{3}(\mathrm{X}=\mathrm{Cl}, \mathrm{Br})$ followed by hydrolysis of reaction mixtures, (arylsulfinyl)allenes give allyl alcohols $\left(\mathrm{ArSO}_{2}-\mathrm{CR}^{1}=\mathrm{CH}-\mathrm{C}(\mathrm{OH}) \mathrm{R}^{2} \mathrm{R}^{3}\right)$. Plausible reaction mechanisms have been proposed for all studied reactions.
\end{abstract}

\section{Introduction}

Allenes are widely explored in organic synthesis for the construction of various molecules [1-7]. In particular, arylsulfonyl $\left(\mathrm{ArSO}_{2}\right)$ allenes are usefull building blocks in miscellaneous transformations. For instance, addition of such allenes to Michael acceptors leading to terminal acetylenes has been recently shown [8]. These allenes give rise to pyrrolidines [9], 
pyrroles [10], chromenes [11], benzoazepinones [12], macrolides [13], and some other carbo- and heterocycles [14-16]. It should be specially emphasized that many compounds containing $\mathrm{SO}_{2}$ groups are drugs, such as, dapson [17], oxicams [18], or amisulpride [19]. Substantial contribution in this area was made by Harmata et al. [20-24]. However, to the best of our knowledge, electrophilic reactions of (arylsulfonyl)allenes have not been widely studied yet. It has been shown by $\mathrm{Ma}$ et al. that $\mathrm{ArSO}_{2}$-allenes take part into halogenohydroxylation $(\mathrm{Hal}=\mathrm{I}, \mathrm{Br})$ or addition-elemination of bromine (forming bromobutadienes) with high stereoselectivity $[25,26]$. Apart from that, reactions of sulfur containing allenes were studied in acidic media [27,28]. Despite promising results, there was no further research in this area.

Based on our recent work on transformations of phosphonoallenes under the action of strong Brønsted or Lewis acids [29-32], we undertook a special study on reactions of (arylsulfonyl)allenes $\mathbf{2 a - j}$ and (arylsulfinyl)allenes $\mathbf{1 a}, \mathbf{b}$ (Scheme 1).
The reaction between proparylic alcohols and arylsulfanyl chlorides followed by acetylene-allene rearrangement was used to prepare (arylsulfinyl)allenes $\mathbf{1}$ according to the literature procedure $[24,25]$. The latter were in situ oxidized to (arylsulfonyl)allenes $\mathbf{2}$ (see X-ray structure of $\mathbf{2 h}$ in Figure 1). Allenes $\mathbf{1 a}, \mathbf{b}$ were specially isolated to compare their reactivity with allenes 2 .

The main goals of this work were the investigation of reactions of sulfur-containing allenes $\mathbf{1}$ and $\mathbf{2}$ under electrophilic activation with Brønsted or Lewis (super)acids, and the study on cationic intermediates of these reactions by means of NMR and DFT calculations.

\section{Results and Discussion}

First, the behavior of allenes $\mathbf{1} \mathbf{a}, \mathbf{b}$ and $\mathbf{2 a}-\mathbf{h}$ in Brønsted acids ( TfOH, $\mathrm{D}_{2} \mathrm{SO}_{4}$ ) was studied by means of NMR (Table 1). Dissolving these allenes in $\mathrm{TfOH}$ or $\mathrm{D}_{2} \mathrm{SO}_{4}$ directly in NMR tubes at room temperature gave intensively colored red solutions of cationic species, which were stable for a long time.

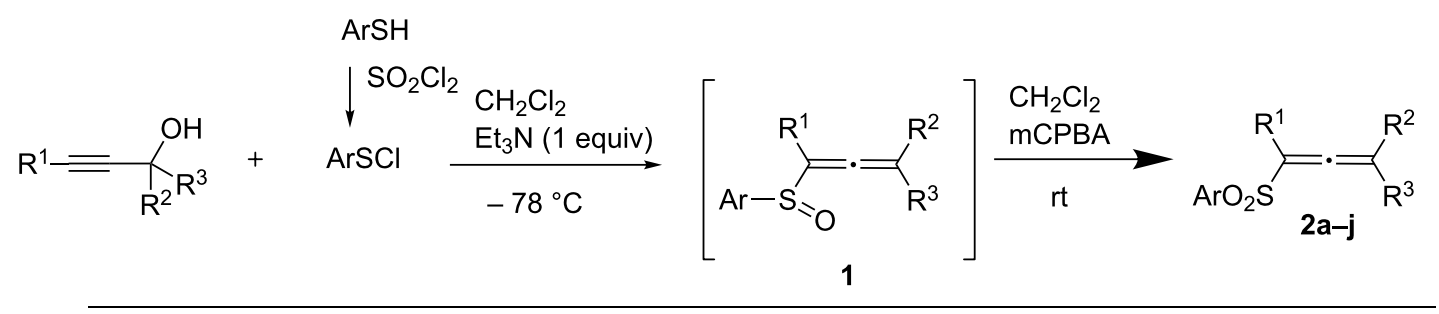<smiles>CC(C)=C=CS(=O)(=O)c1ccccc1</smiles><smiles>CCOS(=O)(=O)C=C=C(C)C</smiles><smiles>CC(C)=C=CS(=O)(=O)c1ccccc1</smiles>

2a $(71 \%)$<smiles>CC(C)=C=C(SOC(C)(C)C)S(=O)(=O)c1ccccc1</smiles>

2 e $(70 \%)$<smiles>CCOS(=O)(=O)C=C=C(C)C</smiles>

2b $(72 \%)$<smiles>CC(C)=C=CS(=O)(=O)OCc1ccccc1</smiles>

2c $(95 \%)$<smiles>CC(C)=C(Br)S(=O)(=O)c1ccccc1</smiles>

2d $(80 \%)$<smiles>C=C=CSOc1ccccc1</smiles>

$2 \mathbf{i}(90 \%)$<smiles>CCCCOC(=C=C(C)C(C)(C)C)C(=C=C(C)C(C)(C)C)c1ccccc1</smiles>

$2 \mathrm{f}(81 \%)$<smiles>C=C=COS(=O)(=O)OCC</smiles> 

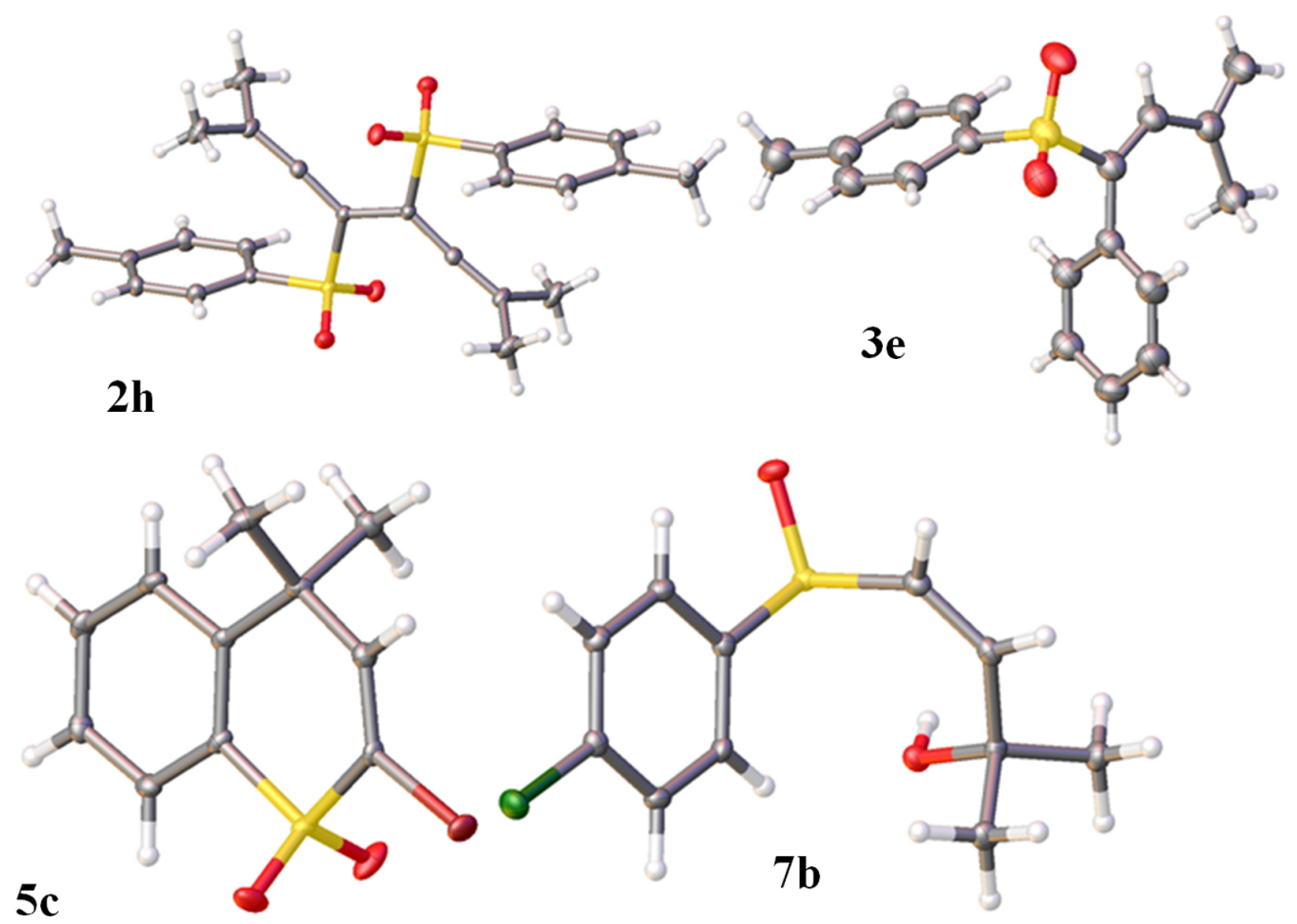

Figure 1: X-ray crystal structures of compounds $\mathbf{2 h}$ (CCDC 1843276), 3e (CCDC 1843277), 5c (CCDC 1580895), 7b (CCDC 1843239); ellipsoid contours of probability levels are $50 \%$.

Table 1: Selected ${ }^{1} \mathrm{H}$ and ${ }^{13} \mathrm{C}$ NMR data for cations $\mathbf{A a}, \mathbf{b}$ and $\mathbf{B a}-\mathbf{h}, \mathbf{P} 1, \mathbf{P} 2$ derived at the protonation of the corresponding allenes at room temperature in $\mathrm{TfOH}$ and $\mathrm{D}_{2} \mathrm{SO}_{4}$.

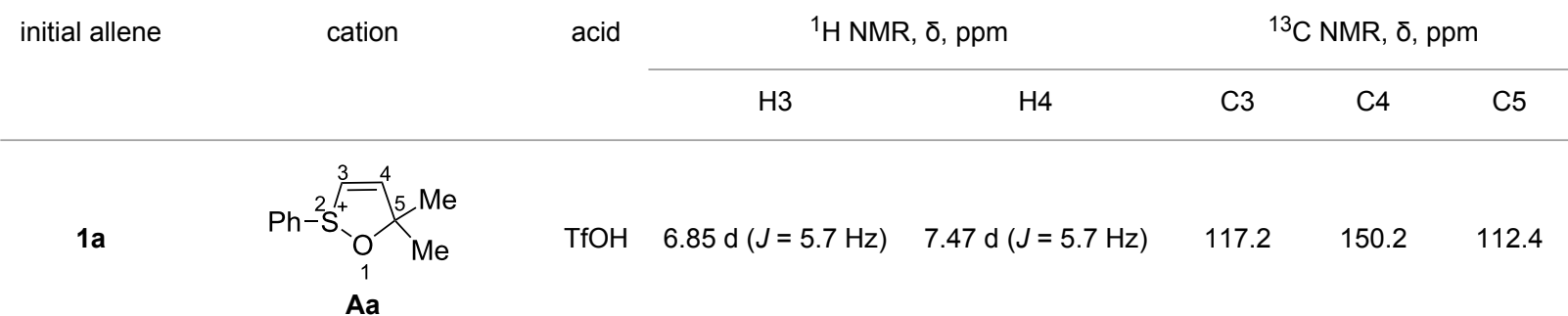

$1 b$

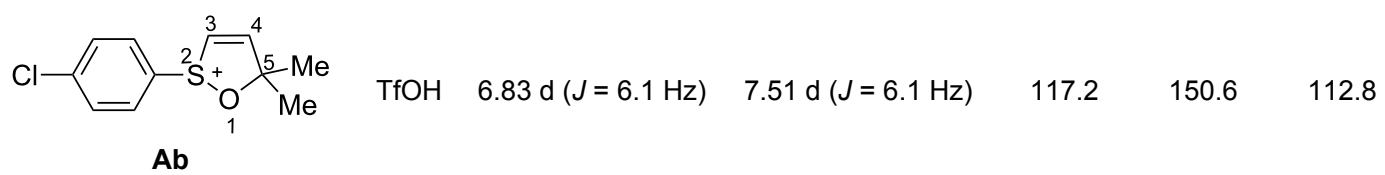

Ab

$2 a$

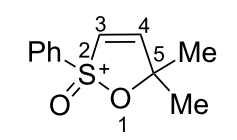

TfOH $\quad 7.16 \mathrm{~d}(J=6.2 \mathrm{~Hz}) \quad 8.05 \mathrm{~d}(J=6.2 \mathrm{~Hz})$

121.0

158.7

112.0

Ba

$2 b$<smiles>CC1(C)C=C[S+](=O)(c2ccc(Cl)cc2)O1</smiles>

$\mathrm{TfOH} \quad 7.17 \mathrm{~d}(\mathrm{~J}=6.0 \mathrm{~Hz}) \quad 8.07 \mathrm{~d}(J=6.0 \mathrm{~Hz}) \quad 122.4$ 
Table 1: Selected ${ }^{1} \mathrm{H}$ and ${ }^{13} \mathrm{C}$ NMR data for cations $\mathbf{A a}, \mathbf{b}$ and $\mathbf{B a}-\mathbf{h}, \mathbf{P} 1, \mathbf{P} 2$ derived at the protonation of the corresponding allenes at room temperature in $\mathrm{TfOH}$ and $\mathrm{D}_{2} \mathrm{SO}_{4}$. (continued)

2c<smiles>Cc1ccc([S+]2(=O)OC(C)(C)C=CC2(C)OC(C)(C)C)cc1</smiles>

$\mathrm{TfOH} \quad 7.12 \mathrm{~d}(J=6.2 \mathrm{~Hz}) \quad 8.01 \mathrm{~d}(J=6.2 \mathrm{~Hz}) \quad 121.3$ 157.1

110.2

2d

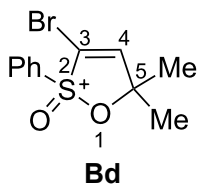

$\mathrm{TfOH}$

$7.95 \mathrm{~s}$

109.9

153.0

112.7

$\mathrm{Br}$

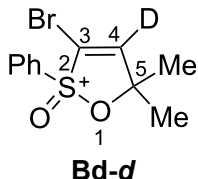

$\mathrm{D}_{2} \mathrm{SO}_{4}$

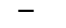

109.0

153.0

113.0

Bd-d<smiles></smiles>

$\mathrm{TfOH}$

$\mathrm{Be}$

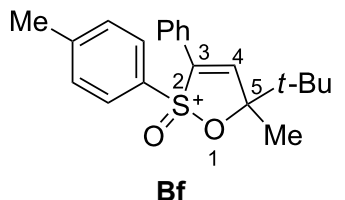

$\mathrm{TfOH}$

$-$

8.02

115.6

154.1

119.3

2 isomers in a ratio of $5: 1^{a}$

$2 g$<smiles>C=CC1(O[Sb](C)(=O)OC)CCCCC1</smiles>

TfOH $\quad 7.11 \mathrm{~d}(J=6.2 \mathrm{~Hz}) \quad 8.02 \mathrm{~d}(J=6.2 \mathrm{~Hz})$

122.6

157.7

114.7

Bg<smiles>Cc1ccccc1</smiles>

$2 \mathrm{~h}$<smiles>[Y6]C1(C)C=C(S(=O)(=O)C(=C)C)[C@@](C)([Si](C)(=O)c2ccc(C)cc2)O1</smiles>

$\mathrm{TfOH}$

$\mathrm{Bh}$

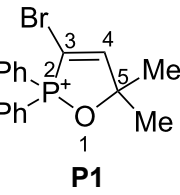

$\mathrm{TfOH}$

$7.78 \mathrm{~d}\left(\mathrm{~J}_{\mathrm{HP}}=28 \mathrm{~Hz}\right)$

102.0

164.3

103.6

ref. [30]

P1

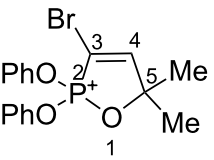

$\mathrm{TfOH}$
$7.84 \mathrm{~d}\left(J_{\mathrm{HP}}=46 \mathrm{~Hz}\right)$

96.0

169.1 
The NMR data, including ${ }^{1} \mathrm{H},{ }^{13} \mathrm{C}$, DEPT, COSY, and HSQC spectra (see Supporting Information File 1), demonstrated unambiguously that compounds $\mathbf{1} \mathbf{a}, \mathbf{b}$ and $\mathbf{2 a}-\mathbf{h}$ underwent cyclization into the corresponding ions $\mathbf{A a}, \mathbf{b}$ and $\mathbf{B a}-\mathbf{h}$ via protonation (deuteration for $\mathrm{D}_{2} \mathrm{SO}_{4}, \mathbf{B d}-\boldsymbol{d}$ ) of the central carbon allenic triad followed by nucleophilic attack of oxygen of the $\mathrm{SO}_{2}$ group (for $\mathbf{B a}-\mathbf{h}$ ) or SO group (for Aa, b) onto the carbocationic center. The similar cyclization was observed for phosphonoallenes (see P1, P2, Table 1) by us previously [30,32]. A new signal of the attached proton $\mathrm{H} 4$ at $\delta 8.05-6.83 \mathrm{ppm}$ range appeared in ${ }^{1} \mathrm{H}$ NMR spectra of species A, B. The comparison of ${ }^{13} \mathrm{C}$ NMR spectra of oxathiolylium A, B and oxaphospholium P1, P2 ions shows that for the former species the signal of carbon C5 is about 10-15 ppm downfield shifted relatively the same signal in the cations P1, P2 (Table 1). This reveals that carbon C5 bears a rather large positive charge in cations $\mathbf{A}, \mathbf{B}$. For dication $\mathbf{B h}$, different signals were detected for quaternary carbons $\mathrm{C} 5$ and C5', and vinyl carbons $\mathrm{C} 4$ and $\mathrm{C} 4$ ', etc., that, probably, indicates formation of two diastereomers (one meso-form and one pair of enantiomers) due to the stereogenic sulfur centers.

In the case of the cation Bf, the signals of two isomers were found in the spectra in a ratio of 5 to 1 . These isomers appear due to cis-, trans-orientation of $t$ - $\mathrm{Bu}$ and ArS groups in the fivemembered ring.

To the best of our knowledge, this is one of the first examples of full NMR characterization of such broad series of cyclic sulfur containing cations Aa,b and $\mathbf{B a}-\mathbf{h}$. Allenes 2i,j did not react with acids at room temperature, however, they react with $\mathrm{TfOH}$ at higher temperature (see below).

To estimate the charge distribution in species Aa, Ba we carried out DFT calculations (Table 2). The calculations confirm the experimental NMR data (Table 1) and prove that C5 does have a large positive charge 0.25 e, which should make this carbon a highly reactive electrophilic center. Another electrophilic center is the sulfur atom, which also bears a large positive charge (1.21-2.06 e). Apart from that, the atomic coefficient of contribution in the LUMO for sulfur is much higher than for $\mathrm{C} 5$. Thus, the electrophilic reactivity of sulfur may be explained by both charge and orbital control. Also, ortho-carbons in the phenyl group bear a negative charge -0.17 to -0.16 e; this means that intramolecular cyclization on these atoms is possible.

To conclude the study on electronic characteristics of 1,2oxathiolylium ions A, B by means of NMR and DFT calculations, one should expect that these species may react in several pathways. First, they may undergo nucleophilic attack on sulfur or on carbon $\mathrm{C} 5$, due to a high positive charge on it. Another pathway may be an electrophilic cyclization at the ortho-carbon in the S-phenyl ring.

Then, the preparative reactions of allene $\mathbf{2}$ a under the action of different electrophilic reagents were conducted. Transformations of $\mathbf{2 a}$ using an excess of various Brønsted acids followed by aqueous quenching of the reaction mixture are shown in Table 3. These reactions resulted in the formation of three different products, $\boldsymbol{Z}-\mathbf{3 a}, \boldsymbol{Z}-\mathbf{4 a}$ and $\mathbf{5 a}$, depending on the reaction conditions. At room temperature in $\mathrm{CF}_{3} \mathrm{SO}_{3} \mathrm{H}$ or $\mathrm{H}_{2} \mathrm{SO}_{4}$ for a short time, $10 \mathrm{~min}$ or $1 \mathrm{~h}$, respectively, butadiene $\boldsymbol{Z}-\mathbf{3 a}$ and alcohol $\boldsymbol{Z}$-4a were formed (Table 3, entries 1 and 3). Increasing the reaction temperature to $60{ }^{\circ} \mathrm{C}$ and the time to $8 \mathrm{~h}$ in $\mathrm{CF}_{3} \mathrm{SO}_{3} \mathrm{H}$ led to the formation of thiochromene 1,1-dioxide 5a (Table 3, entry 2). Decreasing the reaction temperature down to $-60{ }^{\circ} \mathrm{C}$ in $\mathrm{FSO}_{3} \mathrm{H}$ with work-up of the superacidic reaction solution with a low nucleophilic medium (frozen aqueous $\mathrm{HCl}$ at $-60{ }^{\circ} \mathrm{C}$ ) gave almost quantitatively butadiene $\boldsymbol{Z}$-3a with a small admixture of its $E$-isomer (Table 3, entry 4 ). Weaker acids, $\mathrm{CF}_{3} \mathrm{CO}_{2} \mathrm{H}$ or aqueous $\mathrm{HCl}$, did not activate allene $\mathbf{2 a}$, no

Table 2: Selected electronic characteristics of cations Aa, Ba generated from allenes 1a, 2a, correspondingly (DFT calculations). cation $\quad q(S)^{a}$ e $\quad q(C 3)^{a}$ e $\quad q(C 4)^{a}$ e $\quad q(C 5)^{a}$ e $\quad q\left(C_{o-P h}\right)^{a}$ e $\quad k_{L U M O} \%^{b}$

$\mathrm{S} \quad \mathrm{C} 3 \quad \mathrm{C} 4 \quad \mathrm{C} 5 \quad \sum \mathrm{C}_{\mathrm{Ph}(\text { ortho }}+$ para + ipso)

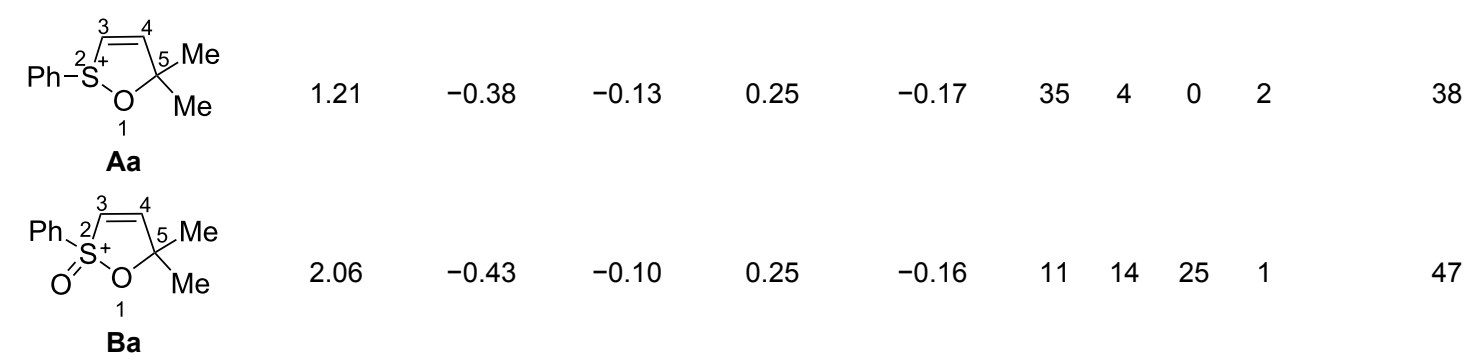

aNatural charges. ${ }^{b}$ Contribution of atomic orbital into the molecular orbital. 
Table 3: Reactions of allene 2a under the action of various Brønsted acids.

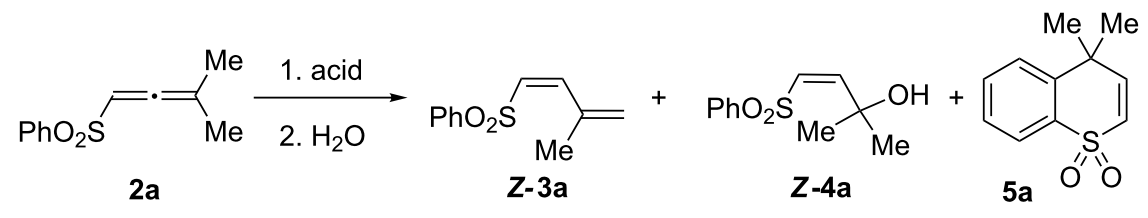

\begin{tabular}{|c|c|c|c|c|c|c|}
\hline \multirow[t]{2}{*}{ entry } & \multicolumn{3}{|c|}{ reaction conditions } & \multicolumn{3}{|c|}{ reaction products, yield, \% } \\
\hline & acid (equiv) & temperature, ${ }^{\circ} \mathrm{C}$ & time & $Z-3 a$ & $Z-4 a$ & $5 a$ \\
\hline 1 & $\mathrm{TfOH}(40)$ & $\mathrm{rt}$ & $10 \min$ & 18 & 81 & - \\
\hline 2 & $\mathrm{TfOH}(40)$ & 60 & $8 \mathrm{~h}$ & - & - & 40 \\
\hline 3 & $\mathrm{H}_{2} \mathrm{SO}_{4}(40)$ & $\mathrm{rt}$ & $1 \mathrm{~h}$ & 20 & 20 & - \\
\hline 4 & $\mathrm{FSO}_{3} \mathrm{H}(40)^{\mathrm{a}}$ & -60 & $1 \mathrm{~h}$ & $90(+\mathbf{E}-3 \mathbf{a}, 9 \%)$ & - & - \\
\hline 5 & $\mathrm{CF}_{3} \mathrm{CO}_{2} \mathrm{H}(40)^{\mathrm{b}}$ & 50 & $24 \mathrm{~h}$ & - & - & - \\
\hline 6 & $\mathrm{HCl}_{\mathrm{aq}}(40)^{\mathrm{b}}$ & $\mathrm{rt}$ & $24 \mathrm{~h}$ & - & - & - \\
\hline
\end{tabular}

aWork-up with frozen aqueous $\mathrm{HCl}$ at $-60{ }^{\circ} \mathrm{C}$. ${ }^{\mathrm{b}}$ Quantitative recovery of starting $2 \mathrm{a}$.

reactions took place (Table 3, entries 5 and 6). Apart from that, Lewis acids of various strength $\left(\mathrm{AlCl}_{3}, \mathrm{AlBr}_{3}, \mathrm{FeCl}_{3}, \mathrm{CeCl}_{3}\right.$, $\mathrm{BF}_{3}-\mathrm{Et}_{2} \mathrm{O}, \mathrm{In}(\mathrm{OTf})_{3}$ ) were found to be ineffective for this transformation, no reactions of allenes $\mathbf{2}$ occurred with them.

Taking into account the data on the formation of cations $\mathbf{B}$ (Table 1), their electronic characteristics (Table 2), and reactions of allene $\mathbf{2 a}$ in Brønsted acids (Table 3), one may propose a plausible mechanism for the transformation of $\mathbf{2 a}$ (Scheme 2). Protonation of the allene system gives cation $\mathbf{C}$, which is cyclized into stable species Ba. Upon work-up of the acidic reaction solution, the fate of the cation Ba strongly depends on the nucleophilicity of the quenching medium. Under the conditions of low nucleophilic work-up with aqueous $\mathrm{HCl}$ (Table 3, entry 4), the deprotonation takes place leading to butadiene
$Z$-3a. The predominant formation of the $Z$-isomer of 3a may reveal that cation $\mathbf{B a}$ undergoes deprotonation and recyclization, rather than species C. Quenching of species Ba with water (high nucleophilicity) affords alcohol $Z$-4a. The formation of compound 4a in exclusively $Z$-configuration may indicate that cation Ba reacts with $\mathrm{H}_{2} \mathrm{O}$ in $\mathrm{S}_{\mathrm{N}} 2$ manner, keeping in mind that carbon $\mathrm{C} 5$ in Ba possesses a large positive charge (see data in Table 1 and Table 2). An alternative mechanism of the formation of alcohol 4a includes the attack of $\mathrm{H}_{2} \mathrm{O}$ on the sulfur electrophilic center giving intermediate $\mathbf{D}$, which is rearranged into alcohol $\boldsymbol{Z}$-4a. Preparation of sulfur heterocycle 5a at high reaction temperature (Table 3, entry 2 ) shows that the intramolecular cyclization to the ortho-carbon of phenyl ring occurs, most probably, through cation $\mathbf{C}$ (Scheme 2). And this reaction has a high activation barrier, analogously to the similar cyclization of

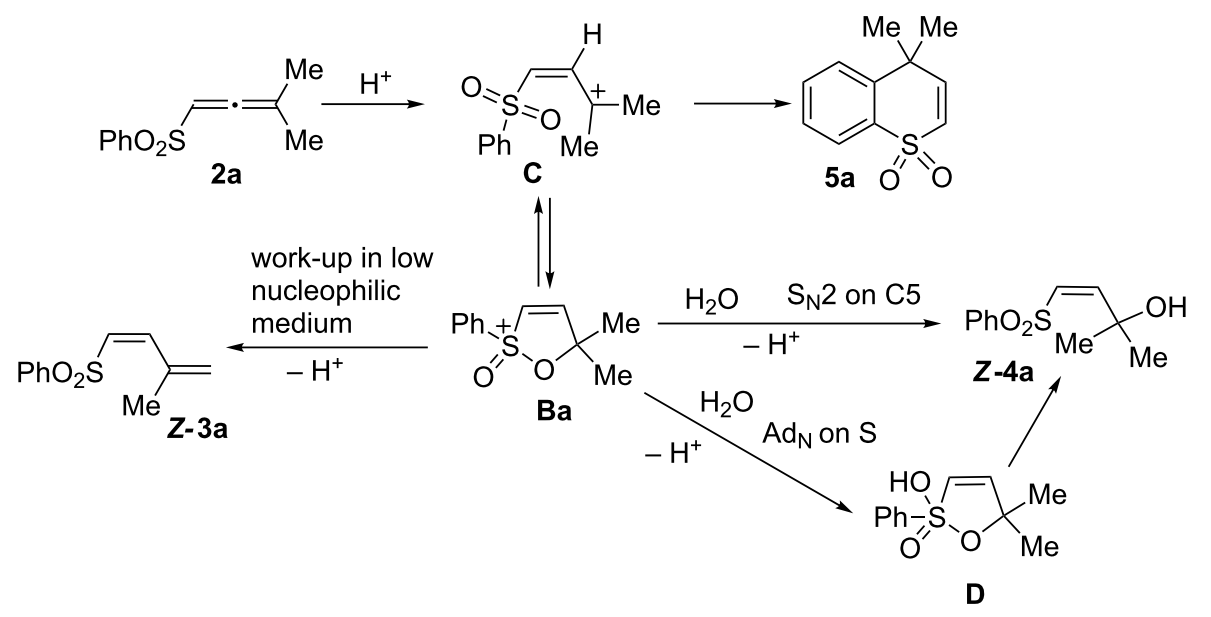

Scheme 2: Plausible reaction mechanisms of transformations of allene 2a in Brønsted acids. 
phosphonoallenes to the corresponding phosphonoheterocycles [30].

We decided to achieve the selective formation of each of these different products, butadienes $\mathbf{3}$, adducts with nucleophiles $\mathbf{4}$, and thiochromene 1,1-dioxides $\mathbf{5}$, from allenes $\mathbf{2}$. The preparation of compounds $\mathbf{3 a}-\mathbf{h}$ was done by the following method (Scheme 3). Reactions of $\mathbf{2 a}-\mathbf{h}$ were carried out in $\mathrm{CH}_{2} \mathrm{Cl}_{2}$ with 1 equivalent of $\mathrm{TfOH}$ to generate the corresponding cations Ba-h. Then, the reaction mixture was cooled down to $-35{ }^{\circ} \mathrm{C}$ and quenched under very mild and low nucleophilic conditions with frozen aqueous $\mathrm{HCl}$ at $-60{ }^{\circ} \mathrm{C}$, that finally led quantitatively to butadienes $\mathbf{3 a}-\mathbf{h}$ (see X-ray structure of $\mathbf{3 e}$ in Figure 1). Worth noting, that compounds $\mathbf{3} \mathbf{a}-\mathbf{h}$ have strictly cis-configuration of $\mathrm{SO}_{2} \mathrm{Ar}$ group and a vinyl substituent at $\mathrm{C} 2$ carbon. It should be mentioned that palladium-catalyzed isomerization of such (arylsulfonyl)allenes $\mathbf{2}$ into trans-butadienes $\mathbf{3}$ was de- scribed recently [23]. Herein, we have developed a novel metalfree approach for the synthesis of cis-isomers of $\mathbf{3}$.

Then, we tried to get selectively products of the nucleophilic attack onto cations B (like structure $\boldsymbol{Z}-\mathbf{4 a}$ in Scheme 2) by quenching of the acidic reaction solutions (in $\mathrm{TfOH}$ ) with various nucleophiles (water, methanol, benzene, acetonitrile). But, in all cases, these reactions were unselective. For instance, for allene 2a, mixtures of butadiene $\boldsymbol{Z}$-3a and alcohol $\boldsymbol{Z}$-4a were obtained. To overcome this obstacle we decided to use 1,1,1,3,3,3-hexafluoropropan-2-ol (HFIP), which was known to form the corresponding ether for further substitution reactions [33]. Indeed, the use of HFIP and a catalytic amount of TfOH (0.1 equiv) followed by hydrolysis allowed to achieve an exclusive formation of allyl alcohols $\boldsymbol{Z}-\mathbf{4 a}, \mathbf{b}$ and $\boldsymbol{E}-\mathbf{4 c}$ from allenes $\mathbf{2 a , b}, \mathbf{d}$, respectively, in high yields (Scheme 4). The most probably, this reaction proceeds through intermediate formation of

$$
\begin{aligned}
& \text { 1.TfOH (1 equiv) } \\
& \mathrm{CH}_{2} \mathrm{Cl}_{2} \text {, rt, } 5 \text { min }
\end{aligned}
$$

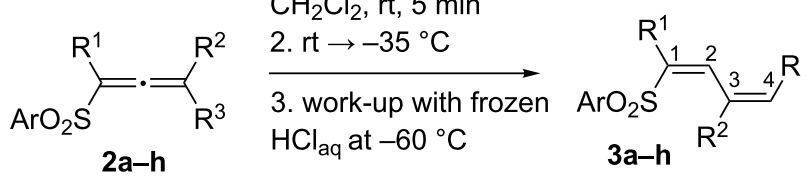

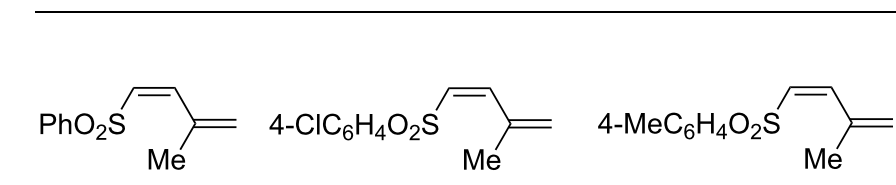

3a $(98 \%)$

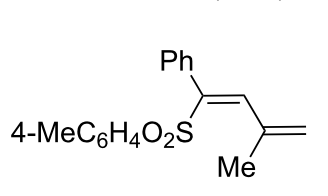

3e $(95 \%)$

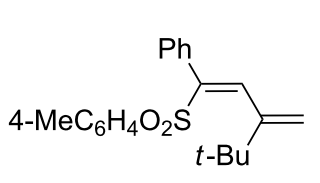

$3 f(87 \%)$

$$
\text { 3c }(94 \%)
$$

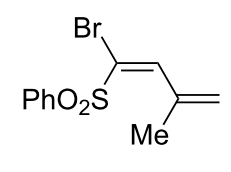

$3 d(88 \%)$<smiles>CCCCOC(C)(C)C</smiles>

$3 g(91 \%)$

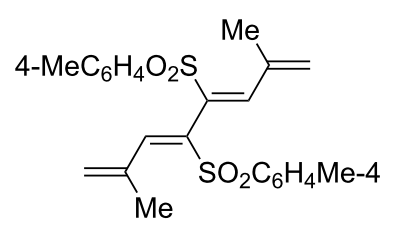

3h $(89 \%)$

Scheme 3: Selective formation of butadienes $3 \mathbf{a}-\mathbf{h}$ from allenes $\mathbf{2 a}-\mathbf{h}$
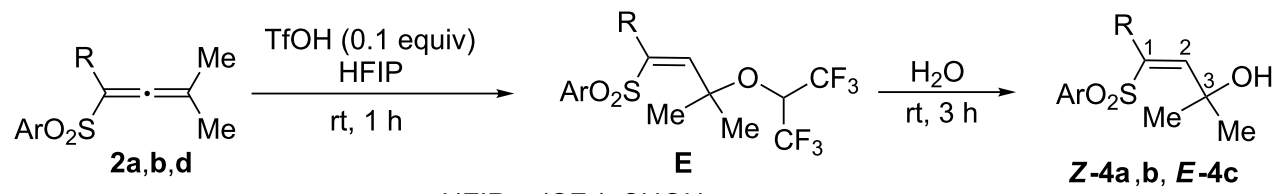

$\mathrm{HFIP}=\left(\mathrm{CF}_{3}\right)_{2} \mathrm{CHOH}$

$Z-4 a, b, E-4 c$<smiles>CC(C)(O)/C=C\S(=O)(=O)Oc1ccccc1</smiles>

Z-4a (99\%)<smiles>CC(C)(O)/C=C\[SH](=O)(O)OCC(C)(C)C</smiles>

Z-4b (78\%)

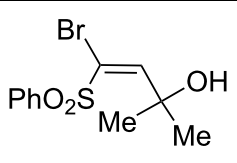

$E-4 c(98 \%)$ 
ethers $\mathbf{E}$ from the corresponding species $\mathbf{B}$. The ethers $\mathbf{E}$ are hydrolyzed to compounds $\mathbf{4}$. Reactions of allenes $\mathbf{2}$ with other nucleophiles (methanol, benzene, acetonitrile) led to the formation of complex mixtures of reaction products. It must be noted that no reaction proceeded in HFIP without $\mathrm{TfOH}$.

The assignment of the cis-configuration of the $\mathrm{ArSO}_{2}$ group and the $\mathrm{C} 3$-substituent in compounds $\mathbf{3}$ and $\mathbf{4}$ was based on the low spin-spin interaction constant of $8.0-11.8 \mathrm{~Hz}$ between the vinyl protons in the ${ }^{1} \mathrm{H}$ NMR spectrum (see Supporting Information File 1) and on comparison with the known trans-isomers of $\mathbf{3}$ [23].

Compounds $\boldsymbol{Z}$-3a and $\boldsymbol{Z}$-4a could be interconverted in acids through species Ba (Scheme 2). Thus, both $\boldsymbol{Z}$-3a and $\boldsymbol{Z}$-4a give cation Ba upon dissolving in TfOH. Then, a different quenching of solution of the cation affords $\boldsymbol{Z}-\mathbf{3 a}$ (Scheme 3) or $\boldsymbol{Z}-\mathbf{4 a}$ (Scheme 5). Heating of the solution of Ba leads to $\mathbf{5 a}$ (see Scheme 5).

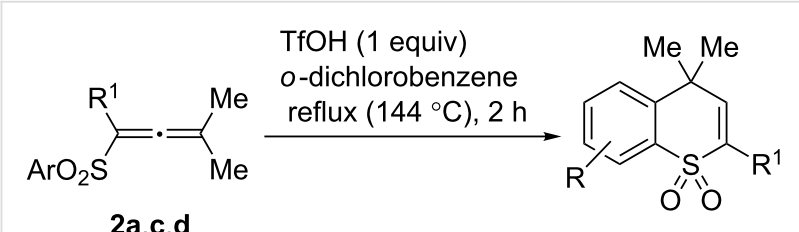

$5 a, b, c$

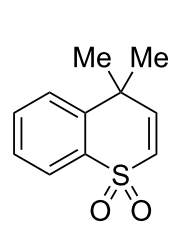

5 a $(80 \%)$

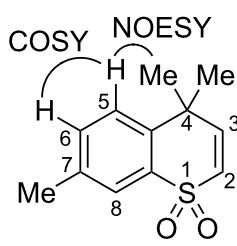

5 b $(85 \%)$<smiles>CC1(C)C=C(Br)S(=O)(=O)c2ccccc21</smiles>

5 c $(91 \%)$
Scheme 5: Formation of thiochromene 1,1-dioxides $\mathbf{5 a - c}$ from allenes 2a,c,d.

The exclusive formation of thiochromene 1,1-dioxides $\mathbf{5 a}-\mathbf{c}$ was obtained by running the reaction of $\mathbf{2 a}, \mathbf{c}, \mathbf{d}$ with 1 equivalent of $\mathrm{CF}_{3} \mathrm{SO}_{3} \mathrm{H}$ at high temperature (reflux in ortho-dichlorobenzene at $144{ }^{\circ} \mathrm{C}$ ) for $2 \mathrm{~h}$ (Scheme 5, see X-ray structure of $\mathbf{5 c}$ in Figure 1). It was found by H,H-NOESY and COSY correla- tions, that there was a [6,7]-shift of the methyl group in the thiochromene system of $\mathbf{5 b}$ obtained from allene $\mathbf{2 c}$, which, at first, should give 6-methyl substituted thiochromene. This shift is caused by the action of superacid at high reaction temperature. Phenyl-substituted allenes 2e,f did not afford the corresponding thiochromenes, due to oligomerization under the harsh reaction conditions. Other allenes $\mathbf{2 g}$,h gave the corresponding heterocycles 5 in very poor yields $(<4 \%$, by GC-MS and ${ }^{1} \mathrm{H}$ NMR data).

As it was mentioned above, unsubsituted allenes $\mathbf{2} \mathbf{i}, \mathbf{j}$ did not react with $\mathrm{TfOH}$ at room temperature (see discussion on NMR of cations $\mathbf{B}$, Table 1). Under the heating in $\mathrm{TfOH}$ at $100{ }^{\circ} \mathrm{C}$ for $0.5 \mathrm{~h}$, these allenes afforded (arylsulfonyl)acetones $\mathbf{6 a}, \mathbf{b}$, which may be formed under the hydrolysis of the formed vinyl triflates F (Scheme 6).

Finally, in this study, we carried out reactions of (arylsulfinyl)allenes 1a,b under superelectrophilic activation with TfOH or $\mathrm{AlX}_{3}(\mathrm{X}=\mathrm{Cl}, \mathrm{Br})$. The corresponding cations Aa,b generated from 1a,b in $\mathrm{TfOH}$ were subjected to quenching with various nucleophiles followed by hydrolysis (Scheme 7). In all the cases, allyl alcohols 7a,b were isolated (see X-ray structure of $\mathbf{7 b}$ in Figure 1). The same alcohols were obtained in reactions of 1a,b with $\mathrm{AlX}_{3}(\mathrm{X}=\mathrm{Cl}, \mathrm{Br})$ after the hydrolysis of reaction solutions. In these reactions, presumably, intermediate

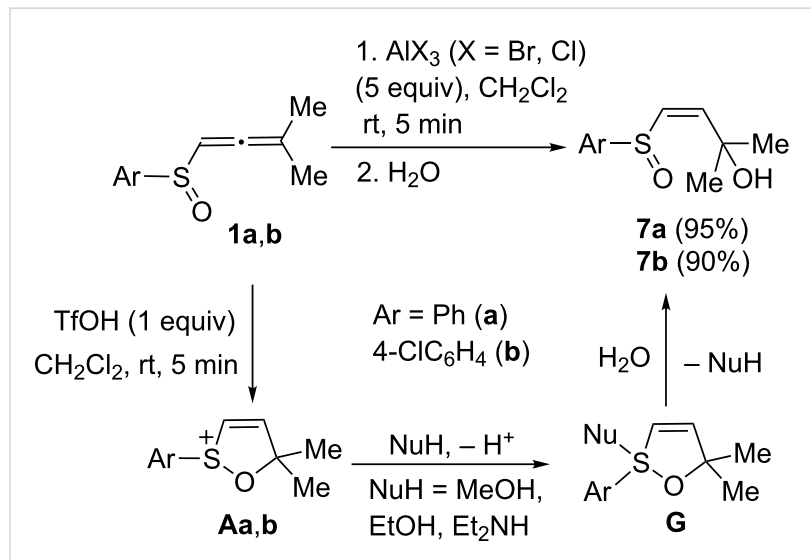

Scheme 7: Reactions of (aryl-sulfinyl)allenes 1a,b under superelectrophilic activation.

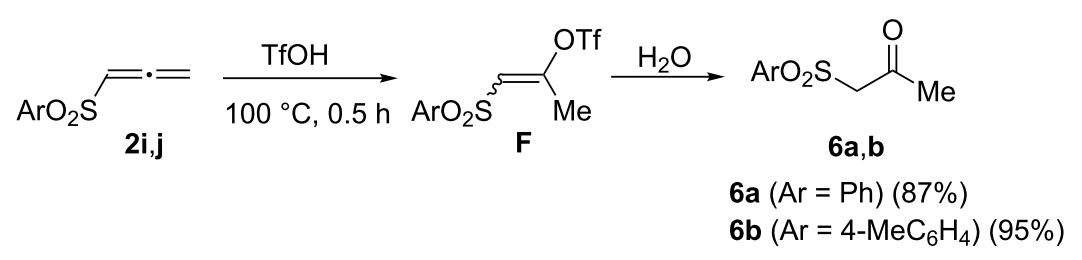


adducts $\mathbf{G}$, which are formed upon interaction of species $\mathbf{A a}, \mathbf{b}$ with nucleophiles, are easily hydrolazible and give rise to alcohols $7 \mathbf{a}, \mathbf{b}$.

\section{Conclusion}

Transformations of (arylsulfonyl)- and (arylsulfinyl)allenes under the action of the Brønsted superacid $\mathrm{TfOH}$, or strong Lewis acids $\mathrm{AlX}_{3}(\mathrm{X}=\mathrm{Cl}, \mathrm{Br})$ have been studied. Under electrophilic conditions, these allenes form the corresponding 1,2oxathiolium ions, which have been studied by NMR and DFT calculations. Depending on electrophilic activator, reaction conditions (temperature, time), and nucleophilicity of media for quenching of solutions of 1,2-oxathiolium ions, these species may undergo various transformations leading to the selective formation of one of the reaction products: conjugated dienes, allyl alcohols, or thiochromene 1,1-dioxides. These reactions open new opportunities for organic synthesis based on electrophilic activation of sulfur containing allenes.

\section{Supporting Information}

\section{Supporting Information File 1}

Copies of ${ }^{1} \mathrm{H}$ and ${ }^{13} \mathrm{C}$ NMR spectra of compounds and cations, X-ray data, and data of DFT calculations. [https://www.beilstein-journals.org/bjoc/content/ supplementary/1860-5397-14-268-S1.pdf]

\section{Acknowledgements}

This work was supported by Russian Scientific Foundation (grant no. 18-13-00008). Spectral studies were performed at Center for Magnetic Resonance, Center for Chemical Analysis and Materials Research, and Research Center for X-ray Diffraction Studies of Saint Petersburg State University, Saint Petersburg, Russia.

\section{ORCID ${ }^{\circledR} \mathrm{iDs}$}

Stanislav V. Lozovskiy - https://orcid.org/0000-0001-7035-0557 Alexander Yu. Ivanov - https://orcid.org/0000-0002-4228-1248 Aleksander V. Vasilyev - https://orcid.org/0000-0003-3628-1492

\section{References}

1. Krause, N.; Hashmi, A. S. K., Eds. Modern Allene Chemistry; Wiley-VCH: Weinheim, 2004; Vol. 1 and 2. doi:10.1002/9783527619573

2. Brummond, K. M.; DeForrest, J. E. Synthesis 2007, 795-818. doi:10.1055/s-2007-965963

3. Bates, R. W.; Satcharoen, V. Chem. Soc. Rev. 2002, 31, 12-21. doi:10.1039/b103904k

4. Ma, S. Aldrichimica Acta 2007, 40, 91-102.

5. Hassan, H. Curr. Org. Synth. 2007, 4, 413-439. doi:10.2174/157017907782408798
6. Back, T. G.; Clary, K. N.; Gao, D. Chem. Rev. 2010, 110, 4498-4553. doi:10.1021/cr1000546

7. Yu, S.; Ma, S. Angew. Chem., Int. Ed. 2012, 51, 3074-3112. doi:10.1002/anie.201101460

8. Martzel, T.; Lohier, J.-F.; Gaumont, A.-C.; Brière, J.-F.; Perrio, S. Adv. Synth. Catal. 2017, 359, 96-106. doi:10.1002/adsc.201600929

9. Lin, T.-Y.; Zhu, C.-Z.; Zhang, P.; Wang, Y.; Wu, H.-H.; Feng, J.-J.; Zhang, J. Angew. Chem., Int. Ed. 2016, 55, 10844-10848. doi:10.1002/anie.201605530

10. Undeela, S.; Thadkapally, S.; Nanubolu, J. B.; Singarapu, K. K.; Menon, R. S. Chem. Commun. 2015, 51, 13748-13751. doi:10.1039/c5cc04871k

11. Kumar, A.; Thadkapally, S.; Menon, R. S. J. Org. Chem. 2015, 80, 11048-11056. doi:10.1021/acs.joc.5b02324

12. Mo, D.-L.; Wink, D. J.; Anderson, L. L. Chem. - Eur. J. 2014, 20 , 13217-13225. doi:10.1002/chem.201403268

13. Xiong, Z.; Hale, K. J. Org. Lett. 2016, 18, 4254-4257. doi:10.1021/acs.orglett.6b02002

14. Mukai, C.; Kobayashi, M.; Kubota, S.; Takahashi, Y.; Kitagaki, S. J. Org. Chem. 2004, 69, 2128-2136. doi:10.1021/jo035729f

15. Mukai, C.; Yamashita, H.; Hanaoka, M. Org. Lett. 2001, 3, 3385-3387. doi:10.1021/ol0101842

16. Mukai, C.; Ukon, R.; Kuroda, N. Tetrahedron Lett. 2003, 44, 1583-1586. doi:10.1016/s0040-4039(03)00067-4

17. Zhu, Y. I.; Stiller, M. J. J. Am. Acad. Dermatol. 2001, 45, 420-434. doi:10.1067/mjd.2001.114733

18. Xu, S.; Rouzer, C. A.; Marnett, L. J. IUBMB Life 2014, 66, 803-811. doi:10.1002/iub.1334

19. Noble, S.; Benfield, P. CNS Drugs 1999, 12, 471-483. doi:10.2165/00023210-199912060-00005

20. Denmark, S. E.; Harmata, M. A.; White, K. S. J. Org. Chem. 1987, 52, 4031-4042. doi:10.1021/jo00227a017

21. Harmata, M.; Cai, Z.; Huang, C. Org. Synth. 2011, 88, 309-316. doi:10.15227/orgsyn.088.0309

22. Tata, R. R.; Hampton, C. S.; Harmata, M. Adv. Synth. Catal. 2017, 359 , 1232-1241. doi:10.1002/adsc.201600986

23. Hampton, C. S.; Harmata, M. Org. Lett. 2014, 16, 1256-1259. doi:10.1021/ol500259m

24. Hampton, C. S.; Harmata, M. J. Org. Chem. 2016, 81, 4807-4822. doi:10.1021/acs.joc.6b00880

25. Ma, S.; Ren, H.; Wei, Q. J. Am. Chem. Soc. 2003, 125, 4817-4830. doi:10.1021/ja034039q

26. Zhou, C.; Fu, C.; Ma, S. Tetrahedron 2007, 63, 7612-7616. doi:10.1016/j.tet.2007.05.039

27. Zhou, C.; Fang, Z.; Fu, C.; Ma, S. J. Org. Chem. 2009, 74, 2887-2890. doi:10.1021/j0802755k

28. Fang, Z.; Zhou, C.; Fu, C.; Ma, S. Org. Biomol. Chem. 2010, 8 , 4554-4561. doi:10.1039/c0ob00007h

29. Bogachenkov, A. S.; Dogadina, A. V.; Boyarskiy, V. P.; Vasilyev, A. V. Org. Biomol. Chem. 2015, 13, 1333-1338. doi:10.1039/c4ob02269f

30. Bogachenkov, A. S.; Dogadina, A. V.; Boyarskaya, I. A.; Boyarskiy, V. P.; Vasilyev, A. V. Org. Biomol. Chem. 2016, 14, 1370-1381. doi:10.1039/c5ob02143j

31. Lozovskiy, S. V.; Bogachenkov, A. S.; Dogadina, A. V.; Vasilyev, A. V. Tetrahedron Lett. 2016, 57, 3167-3170. doi:10.1016/j.tetlet.2016.06.026

32. Lozovskiy, S. V.; Ivanov, A. Y.; Bogachenkov, A. S.; Vasilyev, A. V. ChemistrySelect 2017, 2, 4505-4510. doi:10.1002/slct.201700637

33. Trillo, P.; Baeza, A.; Nájera, C. J. Org. Chem. 2012, 77, 7344-7354. doi:10.1021/jo301049w 


\section{License and Terms}

This is an Open Access article under the terms of the Creative Commons Attribution License

(http://creativecommons.org/licenses/by/4.0). Please note that the reuse, redistribution and reproduction in particular requires that the authors and source are credited.

The license is subject to the Beilstein Journal of Organic Chemistry terms and conditions:

(https://www.beilstein-journals.org/bjoc)

The definitive version of this article is the electronic one which can be found at:

doi:10.3762/bjoc. 14.268 